\title{
XLV. Some speculations on the nature of Instinct
}

\section{Arthur Mower Esq.}

To cite this article: Arthur Mower Esq. (1811) XLV. Some speculations on the nature of Instinct, Philosophical Magazine Series 1, 38:162, 251-254, DOI: 10.1080/14786441108638641

To link to this article: http://dx.doi.org/10.1080/14786441108638641

曲 Published online: 27 Jul 2009.

Submit your article to this journal $\pi$

III Article views: 2

Q View related articles $₫$ 
the proper temperature. When wine is converted into vinegar the alcohol entirely disappears, at least, as M. Chaptal observes, if the acidification is complete. But is alcohol in wine, the only principle which is changed in to vinegar? It has been said, that the other matters contained in the wine contribute to the formation of this acid. Supposing this to be true, it is not less demonstrated that it is essentially by its alcohol that wine is changed into vinegar. What are the chemical cbanges which this substance undergoes in its conversion? This is the object of inquiry.

The phanomena may be explained by referring them to the action of the vegetable fermentable matter, and by attributing them to the influence of the air. In the former case, M. Vauquelin supposes that the fermentable matter separates from the alcohol some of its carbon and hydrogen to form ammonia, and an oily matter, leaving a more oxygenized alcohol, which is the vinegar. In the second case, it is conceived by M. Thenard that the oxygen of the atmosphere attracts the same principles from the alcohol, whence results the formation of water and carbonic acid gas, while the alcohol is converted into water. In both these hypotheses the acidification of the alcohol is attributed to the subtraction of a certain quantity of hydrogen and of carbon from the alconol, which renders the oxyonen predominant in the acetic acid produced. The excess of this oxygen is not very great, because the analysis of this acid by the oxymuriate of potass did not afford MM. Gay Lus. sac and Thenard more than 2.865 of oxygen in addition.

This analysis evidently shows that a very small quantity of oxygen is required to change alcohol into vinegar. It shows also, that vinegar is less oxygenized than any other of the vegetable acids; a very different conclusion from that which places this product as the last term of vegetable oxygenation. From this analysis we can further conceive, how vinegar may so easily be procured by such a variety of different means as have at different times been practised.

XLV. Some Speculations on the Nature of Instinct. By Arthur Mower, Esq.

IHE philosophy of the human mind is a science which of all others is the most backward, and one which by the literary world in general seems to be the least regarded. Whether it is that mankind are tired of metaphysical disputes, and will no longer interest themselves in a theory 


\section{Some Speculations on the Nature of Instinct.}

one day which may be pulled down the next, - whatever may be the cause, - it is certain that, in an æra the most favourable for the arts and sciences, the philosophy of the human mind has made very little advancement. The works of Dugald Stewart, so pure, so elegant, and so profound, will it is to be hoped awaken the attention of men of letters to a science, in which the acquisition of truth more than a hundred-fold repavs the labour of investigation. But with all the deference and admiration which I sincerely feel for the name and works of professor Stewart, yet 1 am not entirely satisfied with the narrow limits he wishes to prescribe to melaphysical speculation. "The legitimate province of this department of philosophy," says Mr. S. "cxtends no further than to conclusions resting on the solid basis of observation and experiment; and I have accordingly, in my own inquiries, aimed at nothing more than to ascertain, in the first place, the laws of our constitution, as far as they can be discovered by attention to the subjects of our consciousness, and afterwards to apply these laws as principles, for the synthetical explanation of the more complicated phænomena of the understanding*." This may be an excellent rule; and it may be very philosophical to condemn that premature inclination to generalize, which has given to the world so many theories. Yet is it not to the love for hypothesis that we owe what little metaphysical truth we at present possess? Would Locke, Berkeley, Hume, Priestley, Hartley, and many others, have ever written on the philosophy of the mind, if they had not wished to bring forward and support some favourite theory? and should we ever bave been favoured with the works of Dr. Reid and Mr. Stewart, if they had had no theories to combat, no rubbish to clear away? One man brings forward a hypothesis ; another sits down with an intention to confute it, and to advance one of his own which he thinks a better, and which in all probability is to be overthrown in its turm. This seems to have been the practice of metaphysicians in every are, and it will be said that they have spent much time and inployed their talents to vory little purpose. It may be so. Aud yet, in the collision of different opinions, there have certainly been struck many sparks of pure genuine truth, sufficiently brilliant to excuse a great deal of error and nonsense, and which but for hypothesis would never have been seen. It frequently happens that, after much study

* Philusophical Essays, Preliminary Diss. p. 3.;-See also several passages to the same effect in the Introduction to his admirable work "Elcments of the Philosophy of the Human Mind." 
and a patient attention to the operations of his own mind, a philosopher feels himself dissatisfied with all theories both ancient and modern; and, beginning to generalize, he forms a hypotbesis of his own, and to one principle perhaps he refers all the phænomena of the human mind. This may be philosophically wrong, but it is very natural; and if any certain theory, without offending religion or common sense, can satisfactorily account for numerous phænomena before unexplained, such a theory is surely not to be rejected because it cannot be proved with the certainty of a mathematical problem. "Si la carise supposée explique tous les phénomènes connus; s'ils se reunissent tous à un même principe, comme autant de lignes dans un centre commun; si nous ne pouvons imaginer d'autre principe qui rende raison de tous ces phénomènes que celui-là, nous, devons tenir pour indubitable l' existence de ce principe *." It is very plain, that without attention " to the subjects of our consciousness," no progress can be made in the philosophy of the human mind; but this attention is in some degree painful. After a tedious observation of mental phænomena, men form a theory by way of relaxation, (they wish to taste the wine before they have pressed the grapes,) and, pleased with their own ingenuity, their hypothesis becomes a creed. This desire then of gencralizing, this propensity to form theories, - which no one feels more than a student in metaphysics, - mav and ought to be controlled, but is not to be too harshly censured nor too much depressed; for though hypothesis frequently proves a dancing meteor which leads its followers into bogs and quagmires, yet it may by chance conduct us into the right road, and to a benighted traveller any light is better than no light at ail.

Your valuable Magazine, which is the vehicle for papers on every other science, has very seldom, I think, if ever, contained a communication on the philosophy of the human mind. In your next number, if you permit me, I will hazard a few observations on that principle which is called Instinct, and which is considered by most people as a sort of mechanical cause of action, both in man and the brute creation. I shall be most happy if the remarks I shall make awaken the attention of some otber correspondent wiser than myself, who will have the goodness to correct me when I am wrong, or to treat the subject himself in a more satisfactory manner. At any rate, there is no harm in

* Eacy. Fran. arcicle Ame, p. rs. 
offering a mite into your treasury. Do not reject my offering because it is a small one : a farthing may be of value at some priod of our lives, though it may remain long at the bottom of our pockets before we have occasion to use it.

\section{Memorandum on the Sulject of the Earl of Elgin's Pursuits in Greece.}

[Continued from p. 215.]

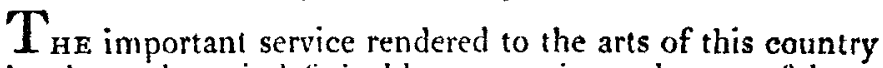
by the zealous, indefatigable, expensive and successful exertions of lord Elgin claim grateful applause from every admirer of the efforts of that kind of human genius which presents to the eye, imitations of nature in a state even superior to what Nature herself exbibits in producing the same forms. Under this impression, and to give every circulation in our power to the detail of his lordship's labours, we intended, when we commenced this article in our last number, to bave given it without any abridgement; but, apprehensive that in doing so we may commit an impropriety, we have determined to give what remains in a more condensed form.

Near the Parthenon are three small temples of the Ionic order, so connected that they might be almost considered as a triple temple. One of them was dedicated to Neptune and Ercchtheus, another to Minerva Polias, and the third to the nymph Pandrosos.

The second of these is of the most delicate and elegant proportions: the capitals and bases of the columns are or. namented with consummate taste; and the sculpture of the frize and cornice is exquisitely rich. The vestibule of the temple of Neptune (now used as a powder magazine) is of more masculine proportions; but its lonic capitals have great merit.

"Both these temples have been measured; and their plans, elevations, and views, made with the utmost accuracy. All the ornanents have been moulded; some originat blocks of the frize and cornice have been obtained from the ruins, as well as a capital and a base.

"The hutleadjoining chapel of Pandrosos is a most singular specimen of Athenian architecture: instead of Ionic columns to support the architrave, it had seven statues of Caryan wonsen, or Caryatides. The Atkenians endeavoured, by this device, to perpetuate the infamy of the inhabitants 